\title{
Self-Report for Assessment of Pain and Quality of Life in Children with Sickle Cell Anemia in a Developing Country
}

This article was published in the following Dove Press journal: Journal of Pain Research

\author{
Valeska Brito da Cunha (iD) \\ Camila \\ Freitas de Andrade Rodrigues (iD \\ Thiago Alves Rodrigues (D) \\ Eduardo José \\ Silva Gomes de Oliveira (D) \\ João Batista Santos Garcia (D) \\ Center for Biological and Health Sciences \\ of the Federal University of Maranhão - \\ CCBS/UFMA, São Luís 65085-582, \\ Maranhão, Brazil
}

Correspondence: Thiago Alves Rodrigues Center for Biological and Health Sciences of the Federal University of Maranhão CCBS/UFMA, Rua do Farol, n. 05. Ed Porto Real, Ap II0I, Ponta do Farol, São Luis, Maranhão 65077-450, Brazil Email thiagoalves2005@gmail.com
Purpose: The specific assessment of pain and quality of life in children with sickle cell anemia (SCA) is still the subject of few studies and is traditionally evaluated through perception of their parents or guardians. Thus, this study aimed to evaluate pain, its characteristics, and impact on the quality of life (QoL) in children diagnosed with SCA, valuing their self-report.

Patients and Methods: This study was conducted on hematology and hemotherapy outpatient clinic in São Luís, Brazil, with children between 7 years and 12 years with SCA, of both genders. The instruments used were Numeric Pain Rating Scale, Faces Pain Scale and Autoquestionnaire Qualité de Vie Enfante Imagé (AUQEI) for the assessment of pain and QoL from the children's self-report. The association between pain intensity and QoL was verified through the Chi-square test and the relationship between pain and the domains of AUQEI was verified through Pearson's correlation, using Stata $10.0^{\circledR}$.

Results: The sample consisted of 104 children with a mean age of 8.97 years, $51.9 \%$ were male and $94.2 \%$ non-white. Pain was characterized predominately moderate to strong, stabbing (37.5\%) and burning (31.7\%), with greater frequency in the limbs, and reported simultaneously in two or more locations. The average pain score was 9.26 at the worst time and in the general context was 6.02. As a result of pain, 93.3\% reported school absence, averaging 8.57 days of absence; $63.5 \%$ had sleep disturbance and $86.5 \%$ failed to perform your daily activities. QoL results were negative in $48.08 \%$ and $56.25 \%$ of these had severe pain. About $74 \%$ of children with positive QoL had mild pain.

Conclusion: Pain in children with SCA has a negative impact on their QoL based on their point of view, affecting their daily life. These findings highlight the importance of valuing children's self-report of the disease, especially in a restricted resource scenario.

Keywords: pain, children, quality of life, sickle cell anemia

\section{Introduction}

Sickle cell disease (SCD), is the most common hematological condition worldwide. ${ }^{1,2}$ Individuals with two sickle hemoglobin alleles (HbSS) have Sickle Cell Anemia (SCA), the most common and severe form of SCD. ${ }^{2}$ It is characterized by recurrent vaso-occlusion events that cause endothelial dysfunction and inflammation, resulting in painful seizures and progressive damage to tissues and organs. $^{2-4}$ These conditions generate serious complications very early in childhood, such as stroke and vasculopathy, as well as an acute thoracic syndrome or vasoocclusive crisis in younger children. ${ }^{1-4}$ 
The incidence of SCD in newborns varies substantially among the states of Brazil, reflecting the ethnic heterogeneity of the Brazilian population. In 2018, the incidence of SCD was 1 in every 1400 newborns in the state of Maranhão, with the same incidence as in the states of Pernambuco, Minas Gerais, and Goiás, second only to Bahia, with 1 in every 650 newborns, and to Rio de Janeiro, with 1 in every 1300 newborns.,

The disease is chronic, it has treatment, but it represents a high degree of suffering for the patient, from a medical, genetic and psychosocial point of view, being associated with several hospitalizations that compromise the quality of life (QoL) and may cause disability. ${ }^{4}$ The most frequent clinical picture of SCD is the pain of occlusive vessel processes, ${ }^{5}$ which is largely responsible for the search for emergency services among patients. ${ }^{6}$ Nevertheless, it is shown that in most of the episodes there is no search for medical treatment, and $90 \%$ of these are treated at home. ${ }^{7,8}$

Pain in children is underestimated and undertreated as the assessment depends on the cognitive development of the child being tested, clinical context, and pain typology. ${ }^{9}$ Also, children are particularly susceptible to suboptimal pain management at all levels of healthcare, particularly in the acute outpatient setting. ${ }^{10-12}$ Analgesia is used too infrequently, often delayed in its administration and dosed too low. ${ }^{10,12}$ This situation of suboptimal pain assessment and management in a child with SCD can lead to a worse quality of life, a factor that can also be underestimated because of how its assessment is realized in children. Performing a more comprehensive pain assessment with easy-to-understand instruments, such as face figures together with other instruments to characterize and measure pain through the children's own account, can help in better understanding how it is affecting them.

QoL in children is traditionally evaluated through the perception of their parents or guardians or a mean of the answers given by parents or guardians and children. This tradition may distance the results obtained from the real perception of the children on the questions used. The development of some QoL measurement instruments (among them the Autoquestionnaire Qualité de Vie Enfante Imagé - AUQEI), ${ }^{13}$ aimed at children, reverses this tradition. The AUQEI is a tool that seeks to evaluate the individual's subjective sense of well-being, starting from the premise that the developing individual is and always has been able to express himself in terms of his subjectivity. ${ }^{13,14}$
Whenever a child can reliably provide his/her data, his/ her reporting is the ideal strategy because it is consistent with the definition of QoL, ${ }^{15}$ which involves three main domains, life at home and in the community, school or work, health and well-being, and their evaluation is not possible without considering them. ${ }^{16}$

Children's self-report of pain and QoL might give a better understanding of their perception of pain. This study represents the first investigation of SCA children's QoL in a reference center in hemoglobinopathies in a city of Brazil. We hypothesized that pain in SCA in this population was associated with low QoL. The aim of this study was to know about pain, its characteristics and its impact on the QoL of children with SCA from the children's own report.

\section{Patients and Methods \\ Study Design}

This is a descriptive and cross-sectional study, conducted between March 2018 to June 2019, carried out in the Hematology and Hemotherapy Center of Maranhão HEMOMAR in the City of São Luís, being the only reference for the treatment of hemoglobinopathies in the whole State of Maranhão, located in the northeast region of Brazil, characterized by being one of the poorest states and having the second-lowest Human Development Index (Maranhão's HDI 0.639) of the country (Brazil's HDI $0.761){ }^{17,18}$

\section{Ethical Aspects}

This study was conducted in accordance with the Declaration of Helsinki. The research was approved by the Ethics and Research Committee on Human Beings of the University Hospital of the Federal University of Maranhão (Number 2485/2011-30). Prior to the study, guardians provided written informed consent, and youth provided assent for participation.

\section{Sample}

The type of sample used was a convenience sample. Children from 7 to 12 years of age, both sexes, with a previous diagnosis of SCA (homozygous SS), were included in the study, were able to answer the questionnaires, accepted to participate in the study and had the results of their guardians. During the data collection period, 189 children were in outpatient follow-up, 163 children were contacted and 104 of these were eligible for the study, as seen in Figure 1. 


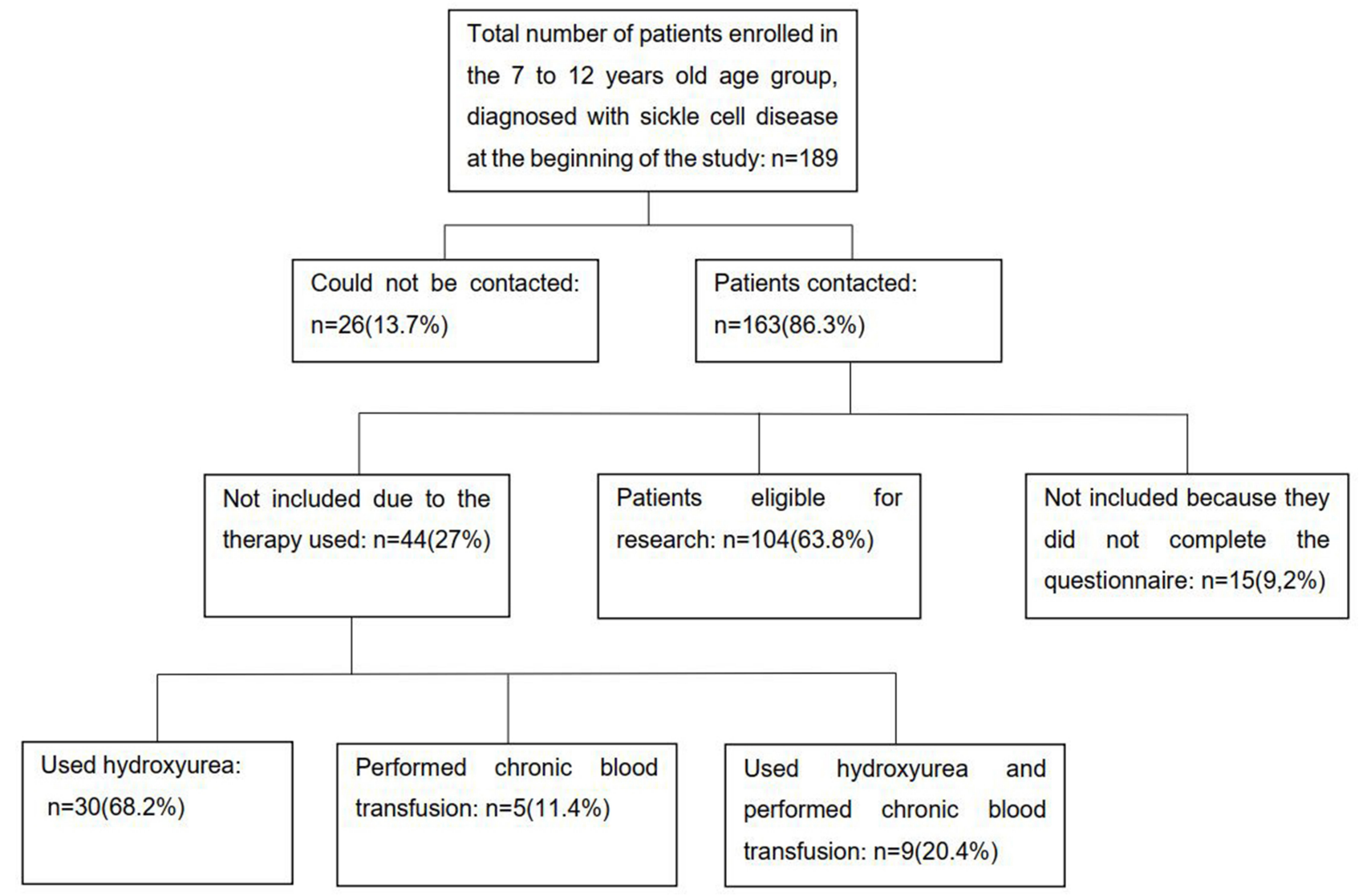

Figure I Allocation flowchart of eligible patients for the study.

\section{Non-Inclusion Criteria}

Patients out of the delimited age, patients and/or parents who do not have the cognitive capacity to understand the questionnaires, as well as children in a scheme of chronic transfusion and/or use of hydroxyurea, were not included in this study, as they have an impact in reducing pain and improving quality of life. ${ }^{19,20}$ Also, it would have differences in the patient evaluation as it is not a readily available treatment scheme for all patients in HEMOMAR and a minority of the patients in the center are on these treatments.

\section{Instruments for Data Collection}

Those responsible for the children who fulfilled the essential requirements for the research were contacted and received an explanation of the objectives and procedures of the study, for their consent. The data were collected through an interview with the children and the pain and QoL questionnaires were applied.

Data collection was carried out between March 2018 to June 2019, by the group of researchers, trained for the interview. The patients were approached before the outpatient care, to take advantage of the waiting opportunity for their consultation.

The acute version of pediatric quality of life questionnaire with seven days recall was administered for the evaluation of pain and its impact on the lives of children, prepared by the researchers was used, containing questions on patient identification (gender, age, race, and address), pain characteristics (intensity, accompanying factors, types, and duration), sleep disturbance, school absence and use of medications, in addition to the application of Numeric Pain Rating Scale (NPRS) and Faces Pain Scale (FPS). ${ }^{9,21}$ The NPRS is graded from zero to ten, in which zero means no pain and ten, the worst possible pain, the scores were categorized in mild (1-3), moderate (4-6) and severe (7-10). In FPS, the patient is asked to point out which face looks more like his when in pain, face number 0 means "no pain" and gradually follows to face number 5 , "unbearable pain". Face number 1 was considered as mild pain, faces number 2 and 3 as moderate pain and faces number 4 and 5 as severe pain. ${ }^{9,21}$ 
The Autoquestionnaire Qualité de Vie Enfante Imagé (AUQEI), was used to assess the quality of life. It is a generic questionnaire for self-assessment of QoL, developed in France in 1997 by Manificat and Dazord, ${ }^{13}$ and translated and validated into Brazilian Portuguese for use in children with age range between 4 and 12 years old. ${ }^{14}$ The use of the AUQEI and its translations in studies/individual clinical practice was subjected to a licensing agreement. The English version of AUQEI Questionnaire - SCRIPT INSERM is available as a Supplementary material file of this paper.

The validation study showed internal consistency represented by a Cronbach's $\alpha$ of 0.71 and external validity $(r=0.497) .{ }^{14}$ The information is obtained together with the individuals, from their point of view regarding their definition of quality of life, including four emotional states ("very happy", "happy", "unhappy" and "very unhappy"). It is a reliable tool for assessment of QoL in children, having its psychometric properties validated for application in children diagnosed with SCA ( $r>0.40$ in $77.8 \%$ of the items and Cronbach's $\alpha$ of 0.68$){ }^{22}$

The questionnaire is divided into two parts using four face figures which present to the child the emotional states of "very sad", "sad", "happy" and "very happy". In the Brazilian Portuguese version, the first part contains four open-ended questions in which the child is asked to describe his or her own experiences for each of the emotional states' alternatives. These questions are exclusively intended to check whether the child understands and identifies the four emotional states through reports of their own experiences. $^{13,14,22}$

The second part is composed of 26 closed questions that explore family relations, social relations, school activities and health status. ${ }^{13,14}$ After the identification stage, the questions are read out one at a time to the child, who is asked to circle the answer which best reflects their emotional state that each situation presented to, with no time limits imposed.

The level of satisfaction in each area is measured by means of four categories of answers, which express an emotional state: very sad (value $=0)$; $\operatorname{sad}($ value $=1)$; happy $($ value $=2$ ); very happy (value $=3$ ). The scoring of the AUQEI is obtained from the sum of the scores assigned to the items of the second part. ${ }^{13,14,20}$ Thus, the variability of AUQEI measurement can range from 0 to 78, where higher scores mean a better quality of life. ${ }^{13,14,22}$ To discuss the total scores, we used the cutoff grade 48, obtained and proposed by the validators of the scale in Brazilian Portuguese,${ }^{14}$ below which a worse QoL is considered.

The second part has 18 of its 26 questions organized into four domains:

- Function: questions relating to school activities, meals, going to bed, and going to the doctor (questions $1 ; 2 ; 4 ; 5 ; 8)$;

- Family: questions relating to the opinion of parental figures and of themselves (questions $3 ; 10 ; 13 ; 16 ; 18$ );

- Leisure: questions concerning holidays, birthday and relations with grandparents (questions $11 ; 21 ; 25$ );

- Autonomy: issues relating to independence, relationship with peers (questions $15 ; 17 ; 19 ; 23 ; 24$ ).

Questions 6, 7, 9, 12, 14, 20, 22 and 26 are not included in the four domains and are of isolated importance because they represent separate domains from the others. ${ }^{13,14}$ This division was proposed by the authors of the AUQEI and the validators of the instrument in Brazilian Portuguese. ${ }^{13,14}$

\section{Data Analysis}

The statistical analysis was performed in the Stata $10.0^{\circledR}$ program. For the numerical variables, means and standard deviations, and frequency distribution for the categorical variables were performed. The association between pain intensity and QoL was verified through the Chi-square test. The relationship between pain and the domains of the QoL questionnaire was performed through Pearson's correlation. It was considered $p<0.05$ statistically significant. All questionnaires were accepted for statistical analysis because there were no unfilled items.

\section{Results}

The children who participated in this study $(\mathrm{n}=104)$ had an average age of 8.97 years, most were male $(51.9 \%)$ and $94.2 \%$ were non-white. All patients complained of pain, which was predominantly in the limbs, more frequently in two or more places and from moderate to strong intensity. In Table 1 we can observe the pain characteristics in these children.

As a consequence of the pain, $93.3 \%$ reported school absence, and the average was 8.57 days. In the children studied in this research, $63.5 \%$ showed sleep disorder when they were in pain and $86.5 \%$ stopped performing their daily activities. Almost all of them (99\%) used some pain medication and of these, $98 \%$ ingested non-opioid analgesics seeking pain relief. Even though they reported 
Table I Pain Profile in Children with SCD from 7 to 12 Years

\begin{tabular}{|c|c|c|}
\hline & $\mathbf{N}$ & $\%$ \\
\hline \multicolumn{3}{|l|}{ Pain } \\
\hline Yes & 104 & 100.0 \\
\hline No & 0 & 0.0 \\
\hline \multicolumn{3}{|l|}{ Localization } \\
\hline Head & 13 & 12.5 \\
\hline Upper limbs & 48 & 46.1 \\
\hline Lower limbs & 65 & 62.5 \\
\hline Thorax & 17 & 16.3 \\
\hline Abdomen & 36 & 34.6 \\
\hline Dorso & 22 & 21.1 \\
\hline \multicolumn{3}{|l|}{ Pain location quantity } \\
\hline One & 29 & 27.9 \\
\hline Two & 55 & 52.9 \\
\hline Three or more & 20 & 19.2 \\
\hline \multicolumn{3}{|l|}{ Pain intensity (NPRS) } \\
\hline Worst moment & \multicolumn{2}{|c|}{$9.26(1.67)^{*}$} \\
\hline General Context & \multicolumn{2}{|c|}{$6.02(3.27)^{*}$} \\
\hline \multicolumn{3}{|l|}{ Pain intensity (FPS) in the general context } \\
\hline Face 5 & 60 & 57.7 \\
\hline Face 4 & 23 & 22.1 \\
\hline Face 3 & 16 & 15.4 \\
\hline Face 2 e I & 5 & 4.8 \\
\hline Face 0 & 0 & 0.0 \\
\hline \multicolumn{3}{|l|}{ Pain characteristics } \\
\hline Burning & 33 & 31.7 \\
\hline Shock & 15 & 14.4 \\
\hline Shooting & 39 & 37.5 \\
\hline Stinging & 11 & 10.5 \\
\hline Cramping & 21 & 20.1 \\
\hline Pressure & 24 & 23.0 \\
\hline Stabbing & 22 & 21.1 \\
\hline \multicolumn{3}{|l|}{ Accompanying factors } \\
\hline Sensibility change & 28 & 26.9 \\
\hline Strenght change & 35 & 33.6 \\
\hline Colour change & 9 & 8.7 \\
\hline Temperature change & 28 & 26.9 \\
\hline Mobility & 8 & 7.7 \\
\hline Edema & 40 & 38.4 \\
\hline Sweating & 13 & 12.5 \\
\hline Paresthesia & 15 & 14.4 \\
\hline
\end{tabular}

Note: *Mean (standard deviation).

Abbreviations: NPRS, Numerical Pain Rating Scale; FPS, Face Pain Scale.

moderate to severe pain, only two $(1.92 \%)$ of the children studied reported the use of opioids.

Regarding the open-ended questions, from the question "Are you sometimes very sad? Tell us why", most answers were related to the children's state of health ("When I get sick", "When I have a pain crisis", "When I go to the hospital", "When I stay in hospital", "When I can't play because it hurts"). In the question "Are you sometimes sad? Say why", the most quoted answers were related to their family and social interactions ("when my friends talk about my illness", "when my parents scold me", "when I go to school "when I am alone"). In the questions related to the "happy" and the "very happy" emotional state, most answers were related to leisure activities ("When I play with my friends", "When I can do sports", "When I go out with my parents", "When I can run").

The total and partial scores on the QoL of children with SCD are shown in Table 2, with a total score that has a possible variation from 0 to 78 . The total mean score was 50.02 points, with a standard deviation of 9.77 . The partial scores by function item and family were the ones with the highest scores, unlike the leisure and autonomy domains.

Table 3 shows nine significant correlations. Six correlations were weakly positive (pain at the worst moment and pain in the general context; function and pain at the worst moment; leisure and function; autonomy and family), two weakly negative (function and pain in the general context; family and pain in the general context) and only a moderately positive correlation (family and function).

For a 95\% confidence interval, a cutoff point of 48 was obtained, below which we can consider as impaired QoL. About 74\% of children with positive QoL had mild pain; however, $48.08 \%$ of children had negative QoL, of these $56.25 \%$ had intense pain. These data can be seen in detail in Table 4.

After the children understood the face figures representing the emotional states of "very sad", "sad", "happy" and "very happy", seen in the first stage, the second stage of AUQEI was applied. Within the "very sad" feeling, the most quoted questions were: "when you stay in hospital" (27.8\%), "when you are away from home" (17.3\%), "when you play alone" (16.3\%) and "when you practice some sport" $(9.6 \%)$. In the "sad" they were: "when you play alone" (66.3\%), "when you are away from home" (64.4\%), "when you stay in hospital" (55.7\%) and "when friends talk about you" (52.8\%). In the answer "happy", we have: "when you see a picture of yourself" (60.5\%), "when you watch television" (59.6\%), "when you are with your grandparents" $(58.6 \%)$ and "at the table, together with your family" (58.6\%). In the "very happy" feeling, we obtained: "when you think of your mother" (55.7\%), "on your birthday" $(42.3 \%)$, "at the table, together with your 
Table 2 Descriptive Measures of the AUQEI Questionnaire Scores and Their Domains

\begin{tabular}{|c|c|c|c|c|c|c|c|}
\hline \multicolumn{8}{|l|}{ Scores } \\
\hline & & \multirow[t]{2}{*}{ Standard Deviation } & \multicolumn{2}{|l|}{ Variation } & \multirow[t]{2}{*}{ Median } & \multirow[t]{2}{*}{$I^{\circ}$ Quartile } & \multirow[t]{2}{*}{$3^{\circ}$ Quartile } \\
\hline & & & Obtained* & Possible* & & & \\
\hline Function & 10.81 & 2.56 & $4-15$ & $0-15$ & 10 & 9 & 13 \\
\hline Family & 9.97 & 2.41 & $3-15$ & $0-15$ & 10 & 8.5 & 11.5 \\
\hline Leisure & 7.00 & 2.42 & $2-6$ & $0-9$ & 7 & 6 & 8 \\
\hline Autonomy & 7.00 & 2.05 & $1-15$ & $0-15$ & 7 & 6 & 9 \\
\hline AUQEI & 50.02 & 9.77 & $23-72$ & $0-78$ & 48 & 43 & 57 \\
\hline
\end{tabular}

Notes: Reproduced with permission from Manificat S, Dazord A, Langue J, et al. Evaluation of the quality of life of infants and very young children: validation of a questionnaire. Multicenter European study. Arch Pediatr. 2000;7(6):605-6I4. ${ }^{13}$ AUQEI @ 1997 Alice Dazord \& Sabine Manificat, All rights reserved. *Minimum-maximum value.

Table 3 Correlation Between Pain and the Four Factors of the AUQEI Questionnaire

\begin{tabular}{|l|l|l|l|l|l|l|}
\hline & NPRS General Context & NPRS Worst Moment & Function & Family & Leisure & Autonomy \\
\hline NPRS general context & 1.00 & & & & \\
NPRS worst moment & $0.34^{*}$ & 1.00 & & & \\
Function & $-0.47^{*}$ & $0.20^{*}$ & 1.00 & & \\
Family & $-0.39^{*}$ & -0.12 & $0.67^{*}$ & 1.00 & & \\
Leisure & -0.13 & -0.07 & $0.30^{*}$ & $0.33^{*}$ & 1.00 & \\
Autonomy & -0.17 & -0.08 & $0.42^{*}$ & $0.33^{*}$ & 0.09 & 1.00 \\
\hline
\end{tabular}

Notes: Reproduced with permission from Manificat S, Dazord A, Langue J, et al. Evaluation of the quality of life of infants and very young children: validation of a questionnaire. Multicenter European study. Arch Pediatr. 2000;7(6):605-614. ${ }^{13}$ AUQEI @ 1997 Alice Dazord \& Sabine Manificat, All rights reserved. Pearson's correlation test; ${ }^{p}<0.001$.

family" (38.4\%), "if you have siblings, when you play with them" (36.5\%). The frequency of the answers for each closed question of the instrument is presented in Table 5 .

\section{Discussion}

The specific assessment of pain and QoL in children with SCD is still the subject of a few studies and is traditionally evaluated through the perception of their parents or

Table 4 Association Between the Quality of Life and Pain Intensity

\begin{tabular}{|l|l|l|l|l|}
\hline \multirow{3}{*}{ AUQEI } & \multicolumn{2}{|l|}{ Pain } & \multirow{2}{*}{ Total } \\
\cline { 2 - 4 } & Mild & Moderate & Severe & \\
\cline { 2 - 4 } & $\mathbf{n}(\%)$ & $\mathbf{n}(\%)$ & $\mathbf{n}(\%)$ & $\mathbf{n}(\%)$ \\
\hline$\geq 48$ & $20(74.07)$ & $13(44.83)$ & $21(43.75)$ & $54(51.92)$ \\
$<48$ & $7(25.93)$ & $16(55.17)$ & $27(56.25)$ & $50(48.08)$ \\
Total & $27(100.00)$ & $29(100.00)$ & $48(100.00)$ & $104(100.00)$ \\
\hline
\end{tabular}

Notes: Reproduced with permission from Manificat S, Dazord A, Langue J, et al. Evaluation of the quality of life of infants and very young children: validation of a questionnaire. Multicenter European study. Arch Pediatr. 2000;7(6):605-6I4. ${ }^{13}$ AUQEI $(1997$ Alice Dazord \& Sabine Manificat, All rights reserved. Chi-square test; $p=0.0276$. guardians. The use of the AUQEI to evaluate QoL in this study aimed to give value to the self-report of young children, with age between 7 and 12 years old, related to pain occurrence and how it impacts their quality of life. It is worth mentioning that such an assessment strategy can make the children feel that their complaints are valued and appreciated by the health care team. Also, AUQEI has low complexity, using faces to express feelings, which makes it easier to understand and fill. Children in this study were inserted in a socioeconomic and cultural context of lower educational levels and family income, making it more important to use a questionnaire that is easily understood.

In this study, all children felt pain ranged from moderate to strong intensity. Patients with pain scores between 6 and 10 (moderate and strong intensity) should receive opioids for symptom relief. ${ }^{23-26}$ However, in our study, most patients were in a suboptimal pain management regimen, as only two of 104 used opioids to treat severe pain. This reveals that there is still a large contingent of severe pain episodes being treated at home, with non-systemized, unplanned, and, in most cases, not very effective analgesic medication, which is a concern.

There is also the fact that health professionals might have fears that the patient will become psychically 
Table 5 Descriptive Analysis of the Questionnaire Items AUQEI

\begin{tabular}{|c|c|c|c|c|}
\hline \multirow[t]{2}{*}{ AUQEI Items (How Do You Feel ...) } & Very Sad & Sad & Happy & Very Unhappy \\
\hline & $\mathbf{N}(\%)$ & $\mathbf{N}(\%)$ & $\mathbf{N}(\%)$ & $\mathbf{N}(\%)$ \\
\hline QI(FU) Around the table, with your Family & I $(0.96)$ & $2(1.92)$ & $61(58.65)$ & $40(38.46)$ \\
\hline Q2(FU) At night, when you go to bed & I (0.96) & $21(20.19)$ & $54(51.92)$ & $28(26.92)$ \\
\hline Q3(FA) In case you have siblings, when you play with them & $2(1.92)$ & $8(7.69)$ & $56(53.85)$ & $38(36.54)$ \\
\hline Q4(FU) At night, while you sleep & 0 & $13(12.50)$ & $60(57.69)$ & $31(29.8 I)$ \\
\hline Q5 (FU) In the classroom & 0 & $9(8.65)$ & $59(56.73)$ & $36(34.62$ \\
\hline Q6(QI) When you see your picture & I (0.96) & $10(9.62)$ & $63(60.58)$ & $30(28.85)$ \\
\hline Q7(QI) When you are playing, at school recess & $5(4.8 I)$ & $12(11.54)$ & $50(48.08)$ & $37(35.58)$ \\
\hline Q8(FU) When you go to the doctor's & $5(4.8 I)$ & $24(23.08)$ & $42(40.38)$ & $33(31.73)$ \\
\hline Q9(QI) When you play sports & $10(9.62)$ & $44(42.31)$ & $22(21.15)$ & $28(26.92)$ \\
\hline QIO(FA) When you think about your dad & $5(4.8 I)$ & $25(24.04)$ & $45(43.27)$ & $27(25.96)$ \\
\hline QII (LE) On your birthday & $5(4.8 I)$ & $9(8.65)$ & $46(44.23)$ & $44(42.31)$ \\
\hline QI2(QI) When you do your homework & $3(2.88)$ & $27(25.96)$ & $50(48.08)$ & $24(23.08)$ \\
\hline QI3(FA) When you think about your mom & $9(8.65)$ & I (0.96) & $36(34.62)$ & $58(55.77)$ \\
\hline QI4 (QI) When you stay in hospital & $29(27.88)$ & $58(55.77)$ & $13(12.50)$ & $\mathrm{I}(0.96)$ \\
\hline QI5(AU) When you play by yourself & $17(16.35)$ & $69(66.35)$ & $13(12.50)$ & $5(4.81)$ \\
\hline QI6(FA) When your dad and your mom talk about you & $5(4.81)$ & $49(47.12)$ & $38(36.54)$ & $12(11.54)$ \\
\hline QI7(AU) When you spend the night at someone else's home & $9(8.65)$ & $52(50.00)$ & $30(28.85)$ & $13(12.50)$ \\
\hline QI8 (FA) When someone asks you to show something that you know how to do & $4(3.85)$ & $25(24.04)$ & $41(39.42)$ & $34(32.69)$ \\
\hline Q19(AU) When your friends talk about you & $10(9.62)$ & $55(52.88)$ & $27(25.96)$ & $12(11.54)$ \\
\hline Q20(QI) When you take the medicines & $9(8.65)$ & $32(30.77)$ & $35(33.65)$ & $28(26.92)$ \\
\hline Q2I(LE) During your vacation & $2(1.92)$ & II (I0.58) & $50(48.08)$ & $41(39.42)$ \\
\hline Q22(QI) When you think about yourself as a grownup & $2(1.92)$ & II (I0.58) & $57(54.8 I)$ & $34(32.69)$ \\
\hline Q23(AU) When you are far from home & $18(|7.3|)$ & $67(64.42)$ & $14(13.46)$ & $5(4.8 I)$ \\
\hline Q24(AU) When you get your grades from school & $5(4.8 I)$ & $19(18.27)$ & $50(48.08)$ & $30(28.85)$ \\
\hline Q25(FA) When you are with your grandparents & $2(1.92)$ & $7(6.73)$ & $61(58.65)$ & $34(32.69)$ \\
\hline Q26(QI) When you watch TV & $2(1.92)$ & $8(7.69)$ & $62(59.62)$ & $32(30.77)$ \\
\hline
\end{tabular}

Notes: Reproduced with permission from Manificat S, Dazord A, Langue J, et al. Evaluation of the quality of life of infants and very young children: validation of

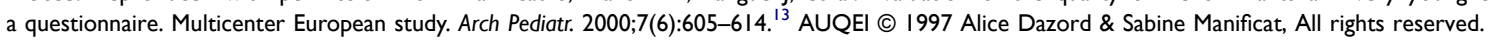

Abbreviations: AU, autonomy domain; FA, family domain; LE, leisure domain; FU, function domain; QI, isolated questions (represents separate domains from others).

dependent if the opioid analgesic is prescribed. ${ }^{25,26}$ It is known, however, that instituting underdoses of analgesics, due to the fear of developing dependence, predisposes patients to search for medication driven by the fear of feeling pain and not having the medication at hand, which demonstrates that the intensity and complexity of pain in SCA are underestimated and poorly understood. ${ }^{24-26}$ Pain episodes in SCA are more intense than postoperative pain or pain secondary to terminal cancer and are associated with lower survival. ${ }^{27-29}$ Therefore, the painful crisis in children with SCA is an emergency and should be promptly evaluated and vigorously treated to achieve relief as soon as possible. ${ }^{24-29}$

The characteristics of pain in SCA do not follow a typical pattern and most patients reported more than one type of pain in most episodes and at various sites, especially in upper and lower limbs, chest, and abdomen. The site of pain that the patient refers to is variable according to each episode and changes from patient to patient. ${ }^{5,24-26,30}$ It can occur in any part of the body, characterizing persistent discomfort to the patient. The episodes are usually acute and can impair the activities of daily life and cause distress in children and their families. ${ }^{7}$

Pain has had an important impact in several areas of daily life, such as school and leisure activities, as observed by some authors. ${ }^{28-30}$ In this study, all patients reported school absence when they were in pain, with a mean absence of 8.6 days, and most children (86.5\%) reported no longer performing their daily activities as a result of the symptoms. These children suffer from the effects of pain attacks, infections, and other significant emergencies, which invariably increase the number of hospitalizations and decrease the hours spent in school and other productive activities. $^{31,32}$

Sleep disturbances in the presence of pain were also significant $(63.5 \%)$, results that would be in agreement 
with other authors, in which pain would also be significantly associated with sleep alterations and with a consequent negative impact on the emotional sphere in these patients. ${ }^{23,27,30}$

In general, it is noticeable that the studies aimed at assessing the QoL of children are reduced. This scarcity is even more evident in studies involving the QoL of children with SCA, which makes it difficult to compare the results found. Thus, the importance of assessing QoL in children with this disease is highlighted, since it can interfere in several ways in their lives. Although AUQEI was not built to evaluate specific domains related to SCD, it has already been applied to children and adolescents with $\mathrm{SCD},{ }^{22}$ being able to show, from the child's perception, their satisfaction with family and social activities and health and body functions. ${ }^{13,14,22}$ It is believed that there is a need to think about subdivisions of AUQEI classification, with graduations as low, medium and high QoL, as well as final and objective scores, since the scale has a cut point only, not showing graduations. ${ }^{33,34}$

Although AUQEI is more accessible and easy to understand, making it easier to use and understand in situations of lower educational level, few studies have used AUQEI to evaluate QoL in children with comorbidities. These researches ${ }^{16,22,34-45}$ had a similar score range to our study, but most were small studies $(\mathrm{n}<30)$, without more detailed statistical analysis and some, compared children with chronic comorbidities to a control group without comorbidities and revealed similar scores..$^{39,41,43,45}$ One study had a significant statistical difference $(\mathrm{p}=0.001$, Mann-Whitney's test), showing that children with cerebral palsy had worse QoL than the control group.

The results in our study suggest that children with SCA, the most severe form of sickle cell disease, have low satisfaction levels with the areas of their daily lives. The open-ended answers revealed through the children's own perception that leisure activities are of great importance for them to have a subjective feeling of well-being with their own lives. Also, it was observed that most of the answers regarding negative experiences included situations that affected their social interactions.

It is also noted in the answers of the second part, that the family was perceived as a source of well-being, corresponding to a significant social institution that presents the potential to influence the process of improving their quality of life. These children are extremely affected by a body that is constantly suffering from pain, requiring continuous care, hospitalization and outpatient treatment, which exposes them to painful, invasive and stressful procedures. ${ }^{46}$

The low scores obtained in the "Autonomy" domain questions reveals that the impairment of search for independence and the development of skills and abilities is greatly perceived by the children, which alerts us to the need to develop actions that make the child more independent and safer, capable of performing their daily activities. ${ }^{22}$ This may be a reflection of the difficulties imposed by the SCA, especially in those who are closer to the transition to adolescence, since they start developing more activities outside the home and far from their parents.

There are still eight questions that are not included in any domain, however, they are included in the global assessment of the child's QoL. ${ }^{13,14,22}$ Among these, the items "hospitalization" and "practicing sports" were those that also had the lowest scores, suggesting that staying in a hospital is considered a malaise for these children because it will be full of medication, stress, and fear. The low score for the item "hospitalization" was also found in other studies. ${ }^{14,20}$ Although data is not available, a possible reason for children not being happy during sport could be because it might trigger pain that they are unable to participate as much as they would like.

There was a positive correlation between function and the other domains, as well as between this and pain, showing that all these variables are related to each other, which draws attention to the harmful influence of pain in a global way on function, leisure, autonomy, and family. The fact that these domains have shown positive correlation may suggest that they measure similar constructs or that one aspect of quality of life may be interfering with each other in one or more domains. A study carried out with children with SCD that did not show a significant correlation between the AUQEI factors, except between autonomy and leisure, in which a moderate correlation was found. ${ }^{20}$ In the questionnaire validation survey, the four dominions that make up the scale obtained a positive correlation between them. ${ }^{14}$

Other questionnaires have already been translated and validated into Brazilian Portuguese to assess QoL in children, ${ }^{30}$ such as the Pediatric Quality of Life Inventory (PedsQL), which has validation for cases of children with $\mathrm{SCD},{ }^{23}$ and most use a mean of guardians and children answer scores to evaluate QoL in children. Researches with different QoL assessment methods also showed results demonstrating the relationship between pain occurrence and intensity in SCD with worse QoL 
scores, even if they had a more inclusive recruitment method, with different genotypes of SCD and including patients who used hydroxyurea and blood transfusion, these studies still support the findings in our study. ${ }^{47-49}$

We found as strengths of this study the use of selfreport to measure the impact of pain in QoL of children with SCA and the capacity to demonstrate a failure in the health system of a developing country to promote adequate pain control, revealing the need for better training related to the treatment of pain for healthcare professionals. It also raises the need of being aware that pain caused by the disease can impact the way it progresses and impact the quality of life. The limitation of the study is the need for better evaluation of the profile of the disease of these patients and their follow-up in the context of low socioeconomic levels of a developing country.

From the data of this study, we concluded that pain in children may be difficult to recognize, as they may lack cognitive capacity or vocabulary to report or describe it, which was observed in this study since some children were not recruited due to this disability. All the children studied felt pain, and through the scales of assessment, most reported that it varied from moderate to strong intensity, at more than one body site, and with different characteristics. They stopped carrying out their daily activities at the time of the painful situation and almost all of them took some medication seeking relief from the pain. As highlighted and discussed throughout this article, the pain has an impact on QoL, influencing the quality of sleep, social and family life of these children with SCA.

\section{Disclosure}

The authors report no conflicts of interest for this work.

\section{References}

1. Piel FB, Patil AP, Howes RE, et al. Global epidemiology of sickle haemoglobin in neonates: a contemporary geostatistical model-based map and population estimates. Lancet. 2013;381(9861):142-151. doi:10.1016/S0140-6736(12)61229-X

2. Kato GJ, Piel FB, Reid CD, et al. Sickle cell disease. Nat Rev Dis Primers. 2018;4:18010. doi:10.1038/nrdp.2018.10

3. Conran N, Belcher JD. Inflammation in sickle cell disease. Clin Hemorheol Microcirc. 2018;68(2-3):263-299. doi:10.3233/CH189012

4. Ballas SK. Sickle cell disease: classification of clinical complications and approaches to preventive and therapeutic management. Clin Hemorheol Microcirc. 2018;68(2-3):105-128. doi:10.3233/CH189002

5. Ministry of Health Brazil. Sickle Cell Disease: Basic Treatment Procedures,2018 [Portuguese]. Ministério da Saúde. Available from: http://bvsms.saude.gov.br/bvs/publicacoes/doenca_falciforme_condu tas_basicas.pdf. Accessed November 16, 2020.
6. Braga JA, Verissimo MP, Saad ST, Cancado RD, Loggetto SR Guidelines on neonatal screening and painful vaso-occlusive crisis in sickle cell disease: associacao Brasileira de hematologia, hemoterapia e terapia celular: project guidelines: associacao medica brasileira $-2016$.

7. Zempsky WT. Evaluation and treatment of sickle cell pain in the emergency department: paths to a better future. Clin Pediatr Emerg Med. 2010;11(4):265-273. doi:10.1016/j.cpem.2010.09.002

8. Smith WR. Pain in sickle cell disease: the future of acute treatment. Expert Rev Hematol. 2011;4(3):237-239. doi:10.1586/ehm.11.28

9. Beltramini A, Milojevic K, Pateron D. Pain assessment in newborns, infants, and children. Pediatr Ann. 2017;46(10):e387-e395. doi:10.3928/19382359-20170921-03

10. Grant PS. Analgesia delivery in the ED. Am J Emerg Med. 2006;24 (7):806-809. doi:10.1016/j.ajem.2006.05.004

11. Brown JC, Klein EJ, Lewis CW, Johnston BD, Cummings P. Emergency department analgesia for fracture pain. Ann Emerg Med. 2003;42(2):197-205. doi:10.1067/mem.2003.275

12. Brudvik C, Moutte S-D, Baste V, Morken T. A comparison of pain assessment by physicians, parents and children in an outpatient setting. Emerg Med J. 2017;34(3):138-144. doi:10.1136/emermed2016-205825

13. Manificat S, Dazord A, Langue J, et al. Evaluation de la qualité de vie du nourrisson et du très jeune enfant: validation d'un questionnaire. Etude multicentrique européenne [Evaluation of the quality of life of infants and very young children: validation of a questionnaire. Multicenter European study]. Arch Pediatr. 2000;7(6):605-614. doi:10.1016/s0929-693x(00)80127-x

14. Assumpção FB Jr, Kuczynski E, Sprovieri MH, Aranha EM. Escala de avaliação de qualidade de vida: (AUQEI-Autoquestionnaire Qualité de Vie Enfant Imagé). Validade e confiabilidade de uma escalapara qualidade de vida em crianças de 4 a 12 anos [Quality of life evaluation scale (AUQEI-Autoquestionnaire Qualité de Vie Enfant Imagé). Validity and reliability of a quality of life scale for children 4 to 12 years-old]. Arq Neuropsiquiatr. 2000;58(1):119-127. doi:10.1590/s0004-282x2000000100018

15. Matza LS, Swensen AR, Flood EM, Secnik K, Leidy NK. Assessment of health-related quality of life in children: a review of conceptual, methodological, and regulatory issues. Value Health. 2004;7(1):79-92. doi:10.1111/j.1524-4733.2004.71273.x

16. Barreire SG, Oliveira OA, Kazama W, Kimura M, Santos VL. Qualidade de vida de crianças ostomizadas na ótica das crianças e das mães [Quality of life of children with stomas: the children and mothers' point of view]. J Pediatr (Rio J). 2003;79(1):55-62.

17. UF IDHM 2010 [Internet]. PNUD brasil. 2020 [cited August 3, 2020]. Available from: https://www.br.undp.org/content/brazil/pt/ home/idh0/rankings/idhm-uf-2010.html. Accessed November 16, 2020.

18. Human Development Reports [Internet]. Hdr.undp.org. 2020 [cited August 3, 2020]. Available from: http://hdr.undp.org/en/countries/pro files/BRA. Accessed November 16, 2020.

19. Badawy SM, Thompson AA, Lai J-S, Penedo FJ, Rychlik K, Liem RI. Health-related quality of life and adherence to hydroxyurea in adolescents and young adults with sickle cell disease. Pediatr Blood Cancer. 2017;64(6):e26369. doi:10.1002/pbc.26369

20. Maxwell SL, Schlenz AM, Kanter J. Health-related quality of life in children with sickle cell disease undergoing chronic red cell transfusion therapy. J Pediatr Hematol Oncol. 2019;41(4):307-312. doi:10.1097/MPH.0000000000001376

21. International Association for the Study of Pain. Faces pain scale. Available from: https://www.iasp-pain.org/Education/Content.aspx? ItemNumber $=1519 \&$ navItemNumber $=577$. Accessed July 25, 2020.

22. Ferreira P, Pinto R, Morales N, Silva C. Propriedades psicométricas do autoquestionnaire qualité de vie enfant imagé (auqei) aplicado em crianças com doença falciforme. Horizonte Científico. 2008;2 (1):47-69. 
23. Menezes ASDODP, Len CA, Hilário MOE, Terreri MTRA, Braga JAP. Qualidade de vida em portadores de doença falciforme. Rev Paul Pediatr. 2013;31(1):24-29. doi:10.1590/s0103-05822013000100005

24. Brandow AM, DeBaun MR. Key components of pain management for children and adults with sickle cell disease. Hematol Oncol Clin North Am. 2018;32(3):535-550. doi:10.1016/j.hoc.2018.01.014

25. Organización Mundial de la Salud. Conjunto de documentos sobre el dolor persistente en niños: Directrices de la OMS sobre el tratamiento farmacológico del dolor persistente en niños con enfermedades médicas. Organización Mundial de la Salud; 2012. Available from: https://apps.who.int/iris/handle/10665/77943. Accessed November 16, 2020.

26. Adegbola MA. Genomics and pain research in sickle cell disease: an explanation of heterogeneity. Nursing. 2011;1-6. doi:10.5402/2011/ 672579

27. Taylor LE, Stotts NA, Humphreys J, Treadwell MJ, Miaskowski C. A review of the literature on the multiple dimensions of chronic pain in adults with sickle cell disease. J Pain Symptom Manage. 2010;40 (3):416-435. doi:10.1016/j.jpainsymman.2009.12.027

28. Zempsky WT. Evaluation and treatment of sickle cell pain in the emergency department: paths to a better future. Clin Pediatr (Phila). 2011;11(4):265-273.

29. Tostes MA, Braga JAP, Len C, Hilário MOE. Avaliação de dor em crianças e adolescentes portadores de doença falciforme [Pain evaluation in children and adolescents with sickle cell disease]. Rev Ciênc Méd. 2008;17(3/6):141-147, maio-dez.

30. Souza JG, Pamponet MA, Souza TC, Pereira AR, Souza AG, Martins AM. Tools used for evaluation of Brazilian children's quality of life [published correction appears in Rev Paul Pediatr. 2015 JanMar;33(1):130]. Rev Paul Pediatr. 2014;32(2):272-278. doi:10.1590/ 0103-0582201432214313

31. Dias T, Oliveira C, Enumo S, Paula K. A dor no cotidiano de cuidadores e crianças com anemia falciforme [Pain the daily life of caregivers and children with sickle cell anemia]. Psicologia USP. 2013;24(3):391-411. doi:10.1590/S0103-65642013000300003

32. Felix A, Souza H, Ribeiro S. Aspectos epidemiológicos e sociais da doença falciforme [Epidemiologic and social aspects of sickle cell disease]. Rev Bras Hematol Hemoter. 2010;32(3):203-208. doi:10.1590/S1516-84842010005000072

33. Panepinto JA, Hoffmann RG, Pajewski NM. A psychometric evaluation of the PedsQL family impact module in parents of children with sickle cell disease. Health Qual Life Outcomes. 2009;7:32. doi:10.1186/1477-7525-7-32

34. Schlindwein-Zanini R, Portuguez MW, Costa DI, Marroni S, Costa JCD. Epilepsia refratária: repercussões na qualidade de vida da criança e de seu cuidador. J Epilepsy Clin Neurophysiol. 2007;13 (4):159-162. doi:10.1590/S1676-26492007000400003

35. Kuczynski E, Silva CA, Cristófani LM, Kiss MH, Odone Filho V, Assumpção FB Jr. Evaluación de la calidad de vida en niños y adolescentes portadores de enfermedades crónicas y/o incapacitadoras: un estudio brasileño [Quality of life evaluation in children and adolescents with chronic and/or incapacitating diseases: a Brazilian study]. An Pediatr (Barc). 2003;58(6):550-555. doi:10.1016/s16954033(03)78120-x

Journal of Pain Research

\section{Publish your work in this journal}

The Journal of Pain Research is an international, peer reviewed, open access, online journal that welcomes laboratory and clinical findings in the fields of pain research and the prevention and management of pain. Original research, reviews, symposium reports, hypothesis formation and commentaries are all considered for publication. The manuscript

Submit your manuscript here: https://www.dovepress.com/journal-of-pain-research-journal
36. Sommerfeld CE, Calmon CM, Sperandio F, Machado A, Beltrame T. Qualidade de vida de crianças em tratamento clínico de leucemia [Quality of life of children in clinical treatment for leucemia]. Brasilia Med. 2011;48:129--37.

37. Andrade ALDL, Alves CAJ, Medeiros M, Galvão HC, Rosa MRD. Quality of life and oral health experience in HIV-infected and non-infected children. Revista Gaúcha De Odontologia. 2012;60 (3):343-348.

38. Elias AV, Assumpção Jr FB Jr. Qualidade de vida e autismo [Quality of life and autism]. Arq Neuropsiquiatr. 2006;64(2A):295-299. doi:10.1590/s0004-282x2006000200022

39. Longo-araujo de Melo E, Moreno-Valdes MT. Evaluacion de la calidad de vida de los ninos con distrofia muscular progresiva de Duchenne [Evaluation of the quality of life of children with Duchenne's progressive muscular dystrophy]. Rev Neurol. 2007;45 (2):81-87. doi:10.33588/rn.4502.2007055

40. Castelo PM, Barbosa TS, Gavião MB. Quality of life evaluation of children with sleep bruxism. BMC Oral Health. 2010;10:16. doi:10.1186/1472-6831-10-16

41. Frota M, Machado J, Martins M, Vasconcelos V, Landin F. Qualidade de vida da criança com insuficiência renal crônica[Quality of life of children with chronic renal failure]. Escola Anna Nery. 2010;14 (3):527-533. doi:10.1590/S1414-81452010000300014

42. Brunelli G, Nogueira PC, Pestana JO, Diniz DH. Quality of life in children on dialysis. Int Urol Nephrol. 2012;44(5):1515-1519. doi:10.1007/s11255-011-0047-2

43. Pfeifer LI, Silva MA. Avaliação da qualidade de vida em crianças com fibrose cística [Assessment of quality of life in children with cystic fibrosis]. Rev Nufen. 2009;2:118-130.

44. de Lorenzo CM, Xikota JC, Wayhs MC, Nassar SM, de Souza Pires MM. Evaluation of the quality of life of children with celiac disease and their parents: a case-control study. Qual Life Res. 2012;21(1):77-85. doi:10.1007/s11136-011-9930-7

45. Barbosa-Resende W, Rangel Vde O, Frontarolli AC, et al. Psychometric properties of the Autoquestionnaire Qualité de Vie Enfant Imagé (AUQEI) applied to children with cerebral palsy. PLoS One. 2015;10(2):e0115643. doi:10.1371/journal.pone.0115643

46. Vijenthira A, Stinson J, Friedman J, et al. Benchmarking pain outcomes for children with sickle cell disease hospitalized in a tertiary referral pediatric hospital. Pain Res Manag. 2012;17(4):291-296. doi:10.1155/2012/614819

47. Sehlo MG, Kamfar HZ. Depression and quality of life in children with sickle cell disease: the effect of social support. BMC Psychiatry. 2015;15:78. doi:10.1186/s12888-015-0461-6

48. Oliveira CDL, Kelly S, de Almeida-neto C, et al. Quality of life in pre-adolescent children with sickle cell disease in Brazil. Pediatr Hematol Oncol. 2019;36(8):457-467. doi:10.1080/08880018.2019. 1660743

49. Ludwig NN, Sil S, Khowaja MK, Cohen LL, Dampier C. Executive functioning mediates the relationship between pain coping and quality of life in youth with sickle cell disease. J Pediatr Psychol. 2018;43(10):1160-1169. doi:10.1093/jpepsy/jsy057

management system is completely online and includes a very quick and fair peer-review system, which is all easy to use. Visit http:// www.dovepress.com/testimonials.php to read real quotes from published authors. 